\title{
A survey of fish species diversity and abundance in the White Volta at Nawuni, Northern Region, Ghana
}

\author{
E. A. OBODAI ${ }^{1 *}$ and M. A. LAWEH ${ }^{2}$ \\ ${ }^{1}$ Department of Fisheries and Aquatic Sciences, University of Cape Coast, Cape Coast, Ghana. \\ ${ }^{2}$ Department of Renewable Natural Resources, University for Development Studies, Tamale, Ghana. \\ *Corresponding author, E-mail: obodai254@yahoo.com,Tel.: (+233) 244085253
}

\begin{abstract}
The study was conducted in the White Volta River at Nawuni to identify the fishing gears used by the fishermen, assess fish species composition and their relative abundance. The results indicated that fishing gears such as gill nets, traps and hook-and-line were used. Most of the net mesh sizes used by the fishermen did not conform to those legally permitted by the Fisheries Department for inland capture fisheries. Forty-three (43) fish species belonging to seventeen (17) families were identified. The family Mochokidae had the highest species representation (7). Cichlidae were the most relatively abundant family (40\%) with Sarotherodon galilaeus, scoring the greatest percentage frequency (29\%). It is recommended that the use of $5.0 \mathrm{~cm}$ mesh size gill net should be encouraged to increase catch on a sustainable basis. Also S. galilaeus is recommended as the best species for culture based on the results of the study. It is concluded that fishing gears of mesh sizes lower than the recommended ones were used by the fishermen, and that the White Volta is rich in fish species diversity.

(C) 2009 International Formulae Group. All rights reserved.
\end{abstract}

Keywords: Fishing gear, species composition, live weight, relative abundance, mesh size, fish families.

\section{INTRODUCTION}

According to FAO (1994), tropical inland waters are the richest in terms of species diversity. The same source also stated that fishing, fish processing and fish trading provide food, employment and generate substantial income to the inhabitants of coastal and inland communities in developing countries, which supply more than half of the world fisheries out put. Fish is a high protein food; hence any increase in fish supply would be a valuable supplement to the world's sources of protein (Tait, 1981). The economic importance of fish to coastal countries has been dealt with by some authors (Bulloch, 1989; FAO, 1996a; 1997a), who claim that fish production by developing countries, for export is more than their export of coffee, banana, rice and other commodities put together. Socially, fishing is an essential source of recreation, community development and cultural values (NMFS, 1995a; FAO, 1997). According to Ejiamatu (1986), fish is free from cultural and religious taboos, and is thus consumed by people of all races and religions.

In spite of the immense socio-economic contributions of fish to the development of developing countries in particular, little has been done by way of scientific research to highlight the role of fish diversity and its sustainability especially in inland waters. A recent work by Dankwa et al. (1999) indicates that of 157 freshwater fish species found in Ghana, 121 of them live in the Volta system. The current work therefore focuses attention 
on fish species diversity and abundance in the White Volta (a tributary of the Volta system) at Nawuni, a village in the Northern Region of Ghana. This is because not much work has been done on fish species diversity in the White Volta at Nawuni.

The specific objectives are to:

(i) identify the fishing gears used;

(ii) identify the fish species in the White Volta and

(iii) determine their relative abundance.

\section{MATERIALS AND METHODS} Study area

The study was conducted in the White Volta at Nawuni, which is located about 40 $\mathrm{km}$ northwest of Tamale, the Northern Regional capital city of Ghana. Nawuni lies between latitudes $9^{\circ} 35^{1}$ and $9^{\circ} 45^{1} \mathrm{~N}$ and longitudes $1^{\circ} 10^{1}$ and $1^{\circ} 25^{1} \mathrm{~W}$. (Figure 1).

\section{Identification of fishing gears}

This was done by interviews and personal observations. This involved interviewing the fishermen using a semistructured questionnaire, which sought to know the types of gears the fishermen used in fishing; and also observing the gears personally, since the author is an expert in fishing gear construction and fishing as well.

\section{Determination of fish species diversity and abundance}

Fish samples were collected daily from 5 fishermen who landed in the morning between 08.00 and 08.30 GMT, from February to May 2003. These 5 were selected out of 9 local fishermen operating in that area, because they used the types of gears identified in the survey, and had agreed to operate daily for the period of the study. The sample size varied between 100 and 150 individual specimens, because the total catches made by the 5 fishermen fell within this range. The different species in the sample size were identified, using two reference materials, namely Holden and Reed (1991) and Dankwa et al. (1999). The different fish species were counted and weighed.

\section{Data analysis}

The data were analysed using simple statistical tools such frequency Tables and histogram.

\section{RESULTS}

Fishing gears

These included seine and gill nets of various mesh sizes: $7.5 \mathrm{~cm}, 6.3 \mathrm{~cm}, 5.0 \mathrm{~cm}$, $4.4 \mathrm{~cm}$ and $6 \mathrm{~mm}$; cast nets of mesh size of $5.0 \mathrm{~cm}$, traps, as well as hook- and -line. Some women were seen using 'baited baskets' for trapping fish, especially Schilbe mystus. The latter method involved putting remnants or leftover food such as cereals and pito marshes in a basket submerged in the river. These attracted the fish and as they came to feed on the leftover food in the basket, they were hauled out and emptied into the boat.

\section{Fish species diversity}

Table 1 shows fish species diversity. The family with the highest number of species (7) was Mochokidae, followed by Characidae and Cichlidae with 6 species each. Claroteidae and Mormyridae were represented by 4 and 3 species, respectively. Four families, namely Claridae, Cyprinidae, Distichodontidae and Polypteridae had 2 species each. The following 8 families were each represented by one species. These were Anabantidae, Bagridae, Centropomidae, Citharinidae, Gymnarchidae, Malapteruridae, Osteoglossidae and Schilbeidae.

\section{Relative abundance in terms of numbers}

The most abundant species was Sarotherodon galilaeus (29.0\%), followed by Synodontis nigrita with $8.7 \%$, Oreochromis niloticus (7.2\%), Schilbe mystus (6.0\%), Citharinus citharus (5.7\%) and Synodontis clarias had $5.4 \%$. Majority of the species had less than $4.0 \%$. These included Labeo coubie and Labeo senegalensis, each of which scored $3.6 \%$. Auchenoglanis occidentalis (2.7\%), Brycinus nurse and Hydrocynus brevis (2.1\%) each, and Distichodus rostratus had $1.8 \%$. The remaining species shown in Table 2 had representations ranging from $1.5-0.3 \%$.

\section{Relative abundance in terms of live weight}

The percentage live weight in figure 2 was the highest for the Cichlids (21.8\%) which were the predominant fish family in this part of the White Volta. Other families with percentage live weights greater than $8.0 \%$ were Characidae (13.7\%), Citharinidae 
Table 1: Checklist of fish species in the White Volta at Nawuni (Feb-May 2003).

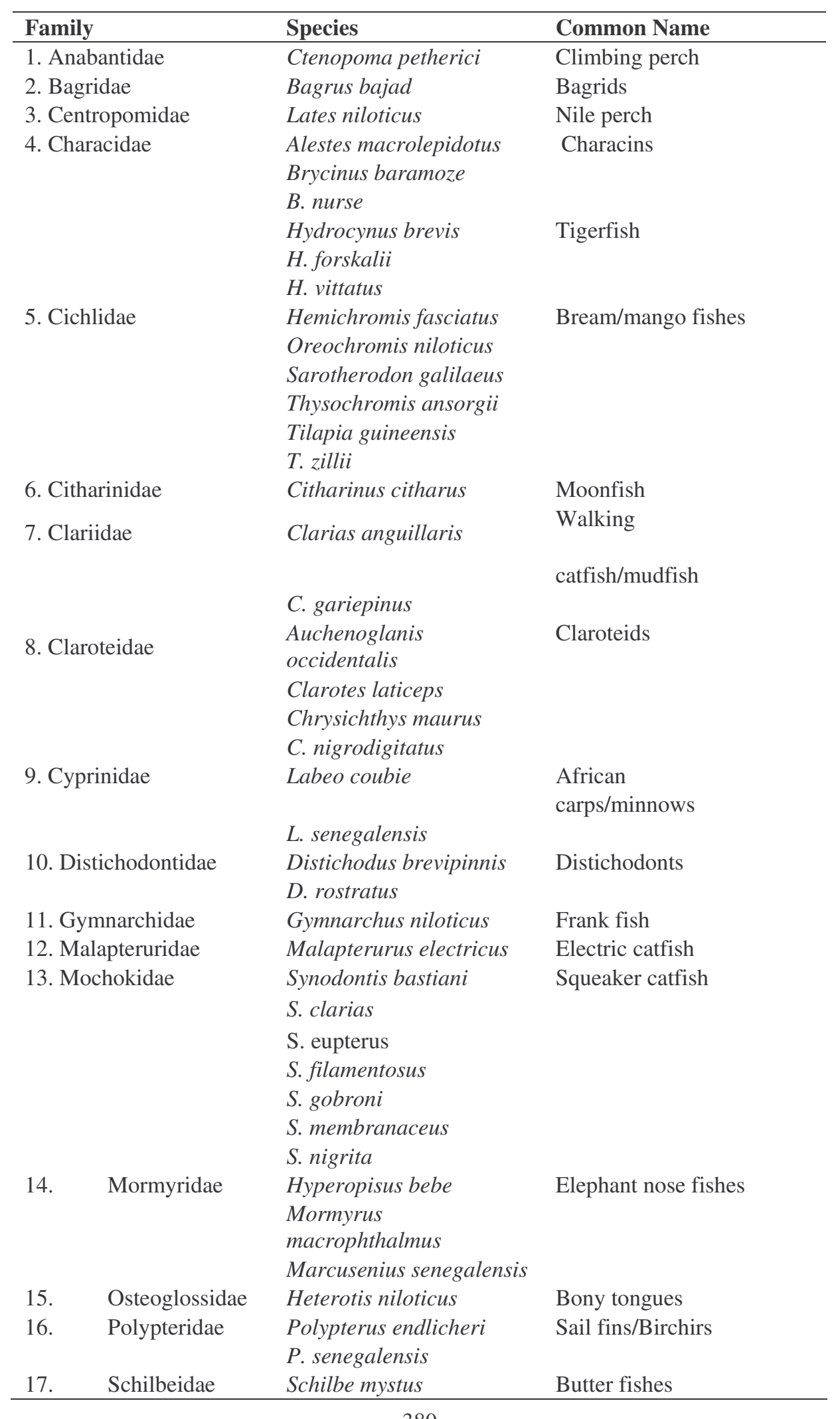


Table 2: Relative Abundance (in terms of numbers) of fish species in the White Volta at Nawuni (February-May 2003).

\begin{tabular}{|c|c|c|c|}
\hline S/N & Species & No & Percentage $(\%)$ \\
\hline 1 & Sarotherodon galilaeus & 97 & 29.0 \\
\hline 2 & S. nigrita & 29 & 8.7 \\
\hline 3 & Oreochromis niloticus & 24 & 7.2 \\
\hline 4 & Schilbe mystus & 20 & 6.0 \\
\hline 5 & Citharinus citharus & 19 & 5.7 \\
\hline 6 & S. clarias & 18 & 5.4 \\
\hline 7 & Labeo coubie & 12 & 3.6 \\
\hline 8 & L. senegalensis & 12 & 3.6 \\
\hline 9 & S. membranaceus & 10 & 3.0 \\
\hline 10 & Clarotes laticeps & 7 & 2.1 \\
\hline 11 & Auchenoglanis occidentialis & 9 & 2.7 \\
\hline 12 & B. nurse & 7 & 2.1 \\
\hline 13 & Hydrocynus brevis & 7 & 2.1 \\
\hline 14 & D. rostratus & 6 & 1.8 \\
\hline 15 & Ctenopoma petherici & 5 & 1.5 \\
\hline 16 & T. zillii & 5 & 1.5 \\
\hline 17 & Mormyrus macrophthalmus & 5 & 1.5 \\
\hline 18 & Tilapia guineensis & 3 & 0.9 \\
\hline 19 & Chrysichthys maurus & 3 & 0.9 \\
\hline 20 & H. forskalii & 3 & 0.9 \\
\hline 21 & Hemichromis fasciatus & 3 & 0.9 \\
\hline 22 & Lates niloticus & 2 & 0.6 \\
\hline 23 & Clarias anguillaris & 2 & 0.6 \\
\hline 24 & C. gariepinus & 2 & 0.6 \\
\hline 25 & C. nigrodigitatus & 2 & 3.6 \\
\hline 26 & Distichodus brevipinnis & 2 & 0.6 \\
\hline 27 & Synodontis bastiani & 2 & 0.6 \\
\hline 28 & Marcusenius senegalensis & 2 & 0.6 \\
\hline 29 & Heterotis niloticus & 2 & 0.6 \\
\hline 30 & Bagrus bajad & 1 & 0.3 \\
\hline 31 & Alestes macrolepidotus & 1 & 0.3 \\
\hline 32 & Brycinus baramoze & 1 & 0.3 \\
\hline 33 & H.vittatus & 1 & 0.3 \\
\hline 34 & Thysochromis ansorgii & 1 & 0.3 \\
\hline 35 & Gymnarchus niloticus & 1 & 0.3 \\
\hline 36 & Malapterurus electricus & 1 & 0.3 \\
\hline 37 & S. eupterus & 1 & 0.3 \\
\hline 38 & S. filamentosus & 1 & 0.3 \\
\hline 39 & S. gobroni & 1 & 0.3 \\
\hline 40 & Hyperopisus bebe & 1 & 0.3 \\
\hline 41 & M. rume & 1 & 0.3 \\
\hline 42 & Polypterus endlicheri & 1 & 0.3 \\
\hline 43 & P. senegalensis & 1 & 0.3 \\
\hline
\end{tabular}




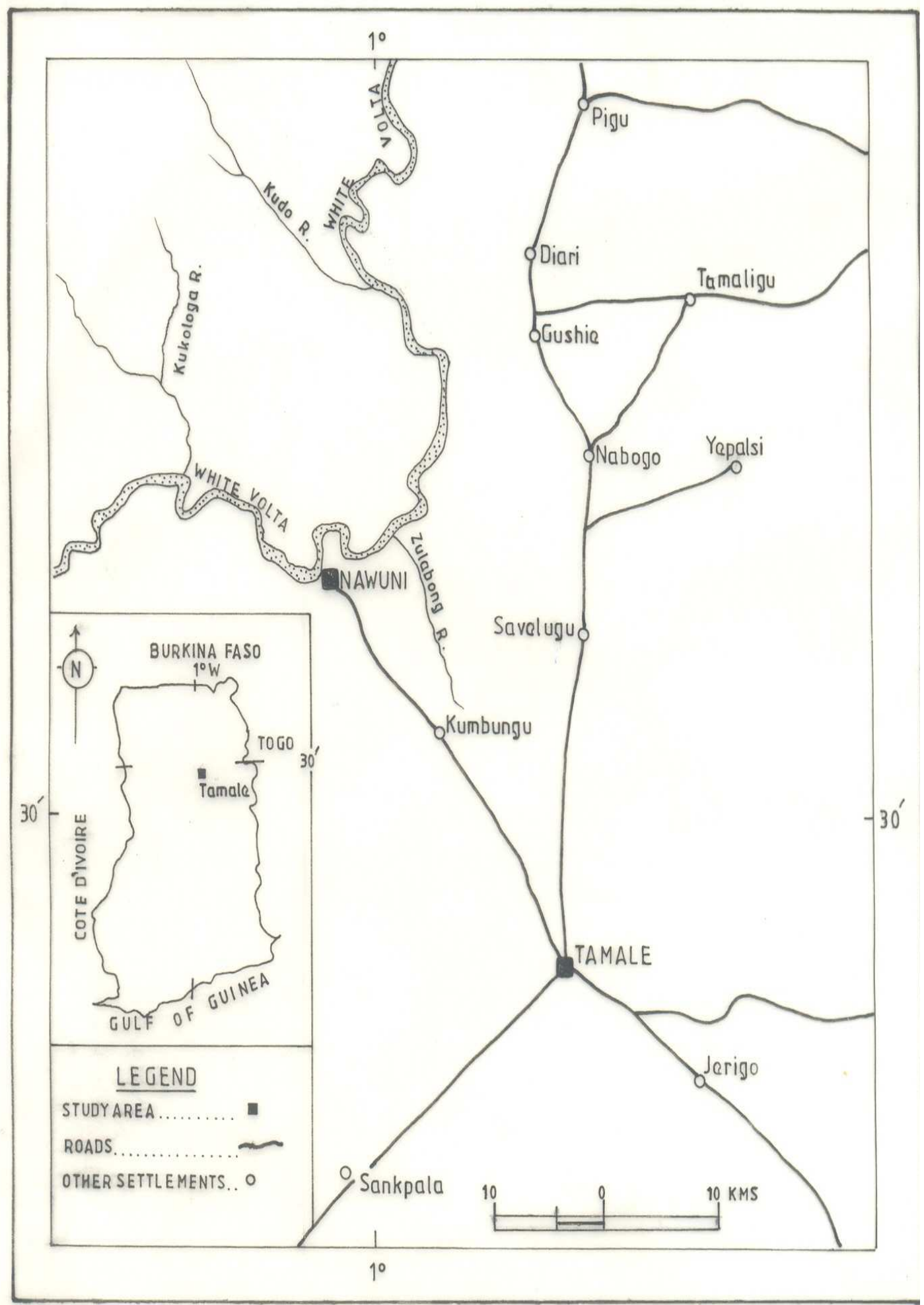

Figure 1: Map of Tolon-Kumbugu and Tamala districts showing the study areas (Nawuni). 


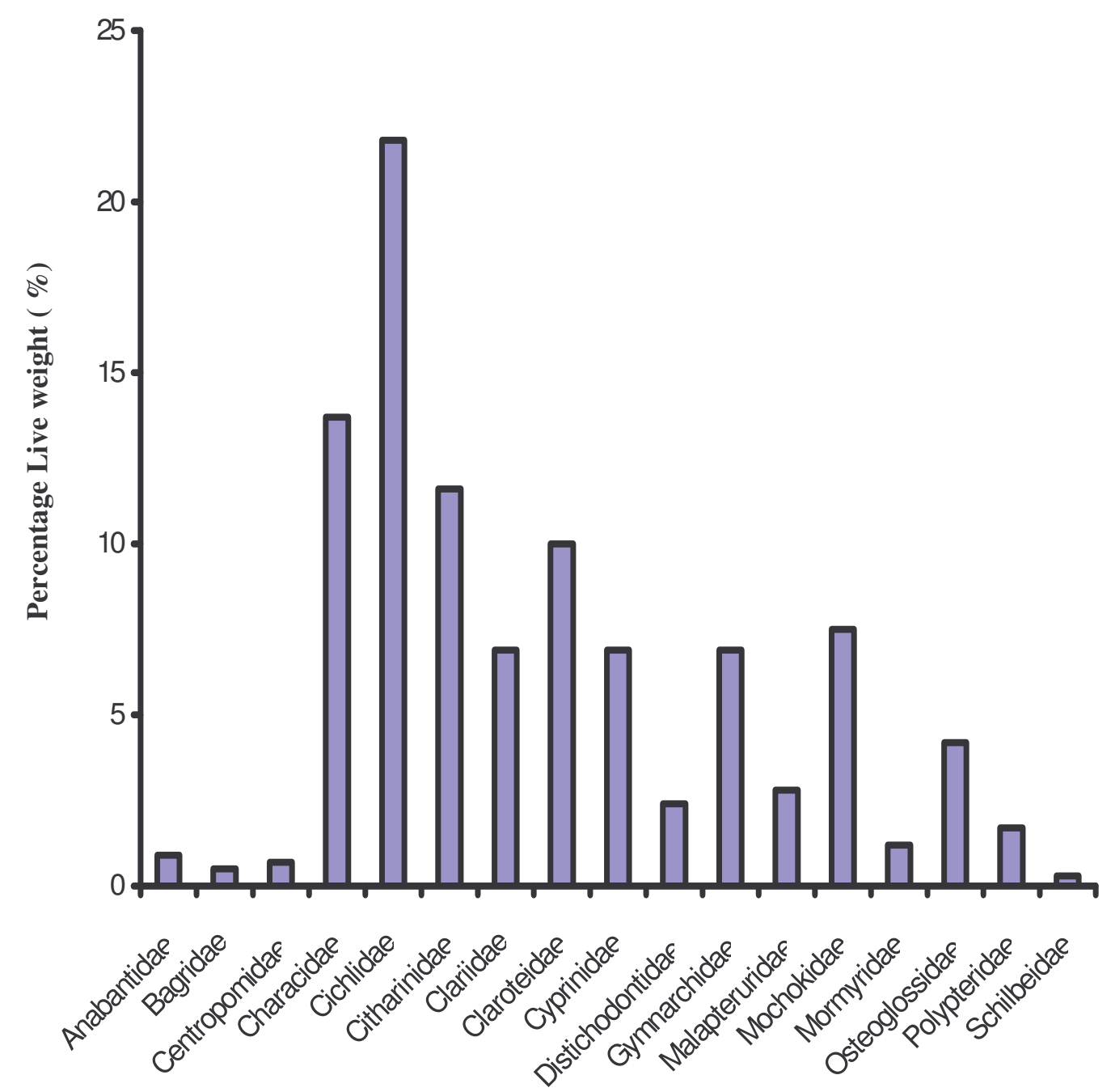

Fish families

Figure 2: Percentage live weight (\%) of fish families produced from the White Volta at Nawuni (February - Mai 2003).

(11.6\%) and Claroteidae (10.0\%), Mochokidae had $7.5 \%$, while three familiesClariidae, Cyprinidae and Gymnarchidaescored $6.9 \%$ each. Fish families with low percentage live weights were Schilbeidae (0.3\%), Bagridae $(0.5 \%)$, Centropomidae $(0.7 \%)$ and Anabantidae (0.9\%). The following families had percentage live weights that ranged between $1.0 \%$ and $4.5 \%$. These were Mormyridae (1.2\%) Polypteridae
(1.7\%), Distichodontidae $(2.4 \%)$ Malapteruridae $(2.8 \%)$ and Osteoglossidae (4.2\%). Total fish caught for the period was $36.09 \mathrm{~kg}$.

\section{DISCUSSION}

The use of nets with mesh sizes below the one legally permitted by the Fisheries Department $(5.0 \mathrm{~cm})$ could pose a serious threat to the fishery resources of the White Volta at this point. The Fisheries Department 
probably needs to enforce this law to protect the fishery resources and mount a campaign to encourage the use of the $5.0 \mathrm{~cm}$ mesh size, because the results of a study, conducted in the Bontanga reservoir by Obodai and Kwofie (2001) indicated that this mesh size was the most efficient of all those tested.

Most inland fish species are juveniles below this size. The exclusive use of $5.0 \mathrm{~cm}$ mesh size would certainly give room for fish fry to mature, since they (fry) would not be caught with gill nets of this mesh size (5.0 $\mathrm{cm})$. This will further improve catches, generate higher income and conserve larger fishes, as this mesh size only does partial harvesting (Obodai and Kwofie, 2001).

The diversity of gear used could result in an even catch of fishes from a range of fish sizes, and not select from a particular size group only.

The high fish diversity obtained in the current survey (43) could be an index of the relatively large area drained by the White Volta (Rosenzweig, 2000). This author reported that the larger the area drained by a water body, the greater the species diversity. The species diversity recorded in this study is much higher than that obtained in the Bontanga Reservoir by Obodai and Kwofie (2001); for the same reason, which explains why the number of species in the Volta Lake at Yeji is greater (60 species) than that of the White Volta at Nawuni. Dankwa et al. (1999) also recorded 121 species of freshwater fishes in the entire Volta system (Ghanaian part only), but did not state the diversity in the White Volta itself.

According to Obodai and Kwofie (2001), the representation of information on relative abundance of fish species, in terms of numbers, tends to over-emphasize the importance of smaller (size) specimens. These co- authors therefore suggested that such data be expressed in percentage live weights. The high representation of the tilapias could be attributed to their high reproductive potential (Trewavas et al., 1972; Hepher and Pruginin, 1981) coupled with practice of parental care in that family (Beveridges and McAndrew, 2000).

The fish families with live weights greater than $4.0 \%$ constitute important commercial and food fishes in West Africa (Holden \& Reed, 1991; Abban et al., 1994).
S. galilaeus is known to spawn much more frequently than the other cichlids (Blakely \& Hrusa, 1989) that practise post-release care, hence their dominance in the catches.

According to Holden and Reed (1991), $S$. galilaeus forms the predominant species where the bed is sandy. Perhaps, a combination of these factors (parental care, high proliferation and sandy bottom of the White Volta at Nawuni) rather than any one of them could be responsible for the current observation.

The rather low level of total fish caught in the period of study $(36.09 \mathrm{~kg})$ might be due to the dry season, when food for fish is usually scarce (Lowe-McConnell, 1977). This author reported that fish catches in the Great Lakes of Eastern Africa dropped considerably during the dry season, and that fish biomass increases rapidly in the rainy season. Scheffer (1998) attributed low occurrence of some freshwater fishes to the abundance of some piscivores, while Trewavas (1983) claimed that low levels of predatory fish populations were a result of competition with their prey during the early stages of the piscivore. The current observation (low catches) which could also be ascribed to fishing pressure (Benndorf et al., 1988) is, however, in sharp contrast with that made by Abban et al. (1994) in the West Gonja Reservoirs. They recorded drops in fish catches as water level increased: an observation they attributed to sudden physical expansion in the size of the reservoirs, due to flooding. Another factor that could have contributed to the low occurrence of the small-sized fishes is the presence of Lates niloticus, which is well known for its voracious predatory (fish-eating) habits (Lowe-McConnell, 1977; Dankwa et al., 1999). The carnivorous activities of $L$. niloticus could have had a devastating effect on the populations of these categories of fishes (small sized).

In conclusion, the survey had revealed that nets of various mesh-sizes, including those far below the recommended ones, were used in the White Volta. Forty-three (43) species belonging to 17 families were encountered. Nine (9) of the families had live weights greater than $4.0 \%$; while the remaining 8 families were poorly represented.

It is recommended that management practices and regulations be enforced. This 
should include restrictions on fishing gears and net mesh sizes, close seasons (during the breeding season) and licensing or registering of fishermen in order to regulate their activities. These should sustain the fishing industry.

\section{REFERENCES}

Abban EK, Ofori-Danson PK, Biney CA. 1994. Fisheries and aquaculture development assessment of impoundments in West Gonja District, Northern, Ghana. IAB Technical Report No.B., $75 \mathrm{p}$.

Benndorf J, Schultz H, Benndorf A, Unger R, Penz E, Kneschke H, Kossatz E, Dumke R, Hornig U, Druspe R, Reichel S. 1988. Food web manipulation enhancement of piscivorous fish stocks long-term effects in the hypertrophic Bautzen Reservoir. East Germany. Limnologia, 19: 97-110.

Beveridges MCM, McAndrew IB. 2000. Tilapias: Biology and Exploitation. Kluwer Academic Publication Data; $184 \mathrm{p}$.

Bulloch KD. 1989. The Wasted Ocean. Lyons and Burford: New York; 150p.

Dankwa HR, Abban EK, Teugels GG. 1999. Freshwater Fishes of Ghana: Identification, Ecological and Economic Importance. Royal Museum for Central Africa: Leuvensesteenweg 283; 53p.

Ejiamatu OI. 1986. Profitable fish farming. (ed.): Tropical farming and food processing Magazine. A Spider Publication $\mathrm{N}^{\circ} 7$.

FAO. 1994. Harvesting nature's diversity. International Journal on Nature Conservation in Africa, 10: 21-22.

FAO. 1996a. Fisheries and Agriculture Organization in Europe: Situation and Outlook in 1996. FAO Fisheries Circular No. 911. Food and Agriculture Organization of the United Nations: Rome; 6-18.

FAO. 1997. A strategic assessment of the potential for freshwater fish farming in
Latin America. Inland Aquaculture Production in Latin America. Copescal Technical paper, No.3.

FAO. 1997a. The state of World Fisheries and Agriculture 1996. Food and agriculture Organization of United Nations: Rome; 113-145.

Hepher B, Pruginin Y. 1981. Commercial Fish Farming with Special Reference to Fish Culture in Israel. John Wiley \& Sons: New York; 261p.

Holden M, Reed W. 1972. West African Freshwater Fish. Longman Group Ltd; 68p.

Lowe-McConnell RH. 1977. Ecology of Fishes in Tropical Waters. Studies in Biology No. 76. Edward Arnold Ltd; 62p.

National Marine Fisheries Service (NMFS). (1995a). Fisheries of the United States, 1994. Current Fisheries Statistics No. 9400. NMFS, US. Department of commerce, Washington, D.C.; 123 - 144.

Obodai EA, Kwofie JE. 2001. Fish species composition and efficiency of selected gill nets used in Bontanga Reservoir. Development Spectrum, an Inter-faculty Journal of the University for Development Studies, l(1): 4-10.

Rosenzweig LM. 2000. Species Diversity in Space and Time. Cambridge University Press; 436p.

Scheffer M. 1998. Ecology of Shallow Lakes. Population and Community Biology Series 22. Chapman and Hall; 2-6 Boundary Row, London. SEI 8HN. 357p.

Tait RV. 1981 Elements of Marine Ecology ( $3^{\text {rd }}$ edn). Butterworths: London; 356p.

Trewavas E. 1983. Tilapine Fishes of the Genera Sarotherodon Oreochromis And Dana Kilia. British Museum: London.

Trewavas E, Green J, Corbet SA. 1972. Ecological studies on crater lakes in West Cameroon. Fishes of Barombi Mbo. J. Zool., 167: 41- 95. 